\title{
KRZYŻ JAKIEGO NIE ZNAMY
}

Znak krzyża to nie tylko dwie przecinające się linie. W wielu kulturach krzyż jako motyw ornamentalny i znak symboliczny należy do najbardziej rozpoznawalnych znaków świata ${ }^{1}$. Jest jednym z najstarszych symboli ludzkości. Znany był już w czasach prehistorycznych ${ }^{2}$ i starożytnych ${ }^{3}$. Był dziełem ludzkich rąk i natury. Jako gest, symbol, amulet znany był na długo przed chrześcijaństwem ${ }^{4}$. Jednakże przez wieki, stał się najważniejszym symbolem chrześcijaństwa. Przybiera on rozmaite znaczenia w zależności od kształtu i kontekstu ${ }^{5}$.

Podstawowymi elementami krzyża są dwie belki: pionowa i pozioma przecinające się pod kątem prostym. Oprócz podstawowej formy spotyka się liczne i różne warianty krzyża zależne od układu belek.

\footnotetext{
* Alina Czachorowska - mgr historii; kustosz w Bibliotece Uniwersyteckiej KUL; e-mail: alina.czachorowska@kul.pl

** Jolanta Wasilewska - mgr historii sztuki; starszy kustosz dyplomowany w Bibliotece Uniwersyteckiej KUL; e-mail: jolanta.wasilewska@kul.pl

1 „Znak krzyża jest stary jak świat, cóż bowiem może być prostszego nad skrzyżowanie dwóch linii”. W. Korabiewicz, Śladami amuletu, Warszawa 1974, s. 9.

${ }^{2}$ Najstarsze znane przedmioty zdobione znakiem krzyża pochodzą z późnego mezolitu i datowane są na 8000 lat p.n.e. A. Sepioł, Krzyż - znak wiary i kultury, Jasło 2013, s. [1].

${ }^{3}$ Spotykany był także w starożytnych Indiach, Dalekim Wschodzie i Egipcie R. Taylor, Przewodnik po symbolice Kościoła, Warszawa 2000, s. 61.

${ }^{4}$ S. Kobielus, Krzyż Chrystusa. Od znaku i figury do symbolu i metafory, Tyniec 2011, s. 16.

${ }^{5} \mathrm{~W}$ sztuce wczesnochrześcijańskiej krzyż jako symbol zbawienia przedstawiano w połączeniu z innymi motywami charakterystycznymi dla poszczególnych wspólnot Kościoła. E. Gigilewicz, Formy krzyża, w: Krzyż, red. E. Kasjaniuk, Lublin 2011, s. 65.
} 


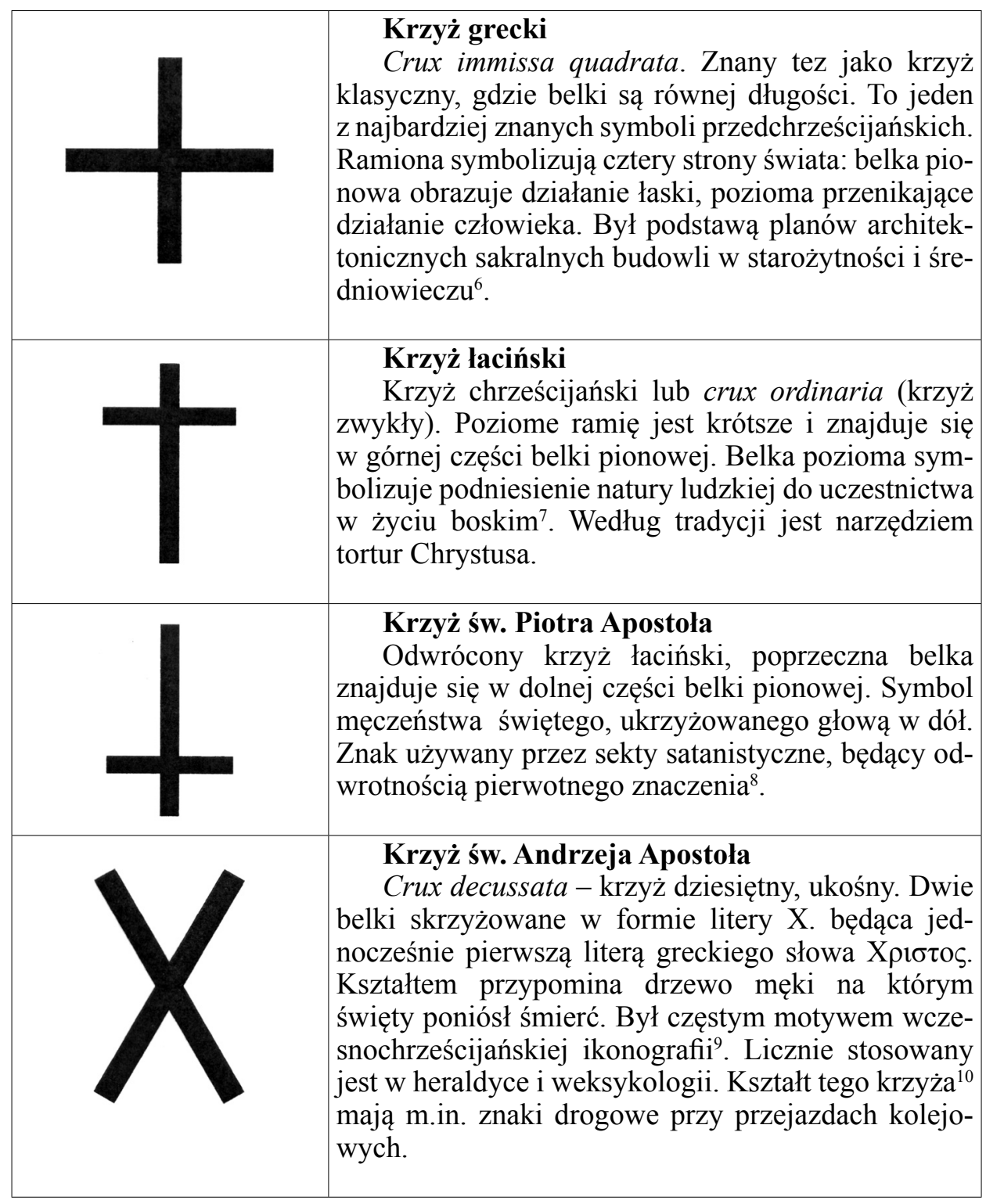

${ }^{6}$ B. Filarska, Poczatki sztuki chrześcijańskiej, Lublin 1986 s. 208.

${ }^{7}$ Gigilewicz, Formy krzyża, s. 65.

${ }^{8}$ Tamże.

${ }^{9}$ M. Lurker, Przestanie symboli w mitach, kulturach i religiach, Kraków 1994, s. 385.

${ }^{10}$ Odgrywał wielką rolę w tysiącletnim rozwoju zarówno znaków umieszczanych na domach, znaków cechowych i granicznych oraz stempli drukarskich. Pierwotnie symbolizował drewna skrzyżowane i położone na ołtarzu ofiarnym. D. Forstner, Świat symboliki chrześcijańskiej, Warszawa 1990, s. 15. 


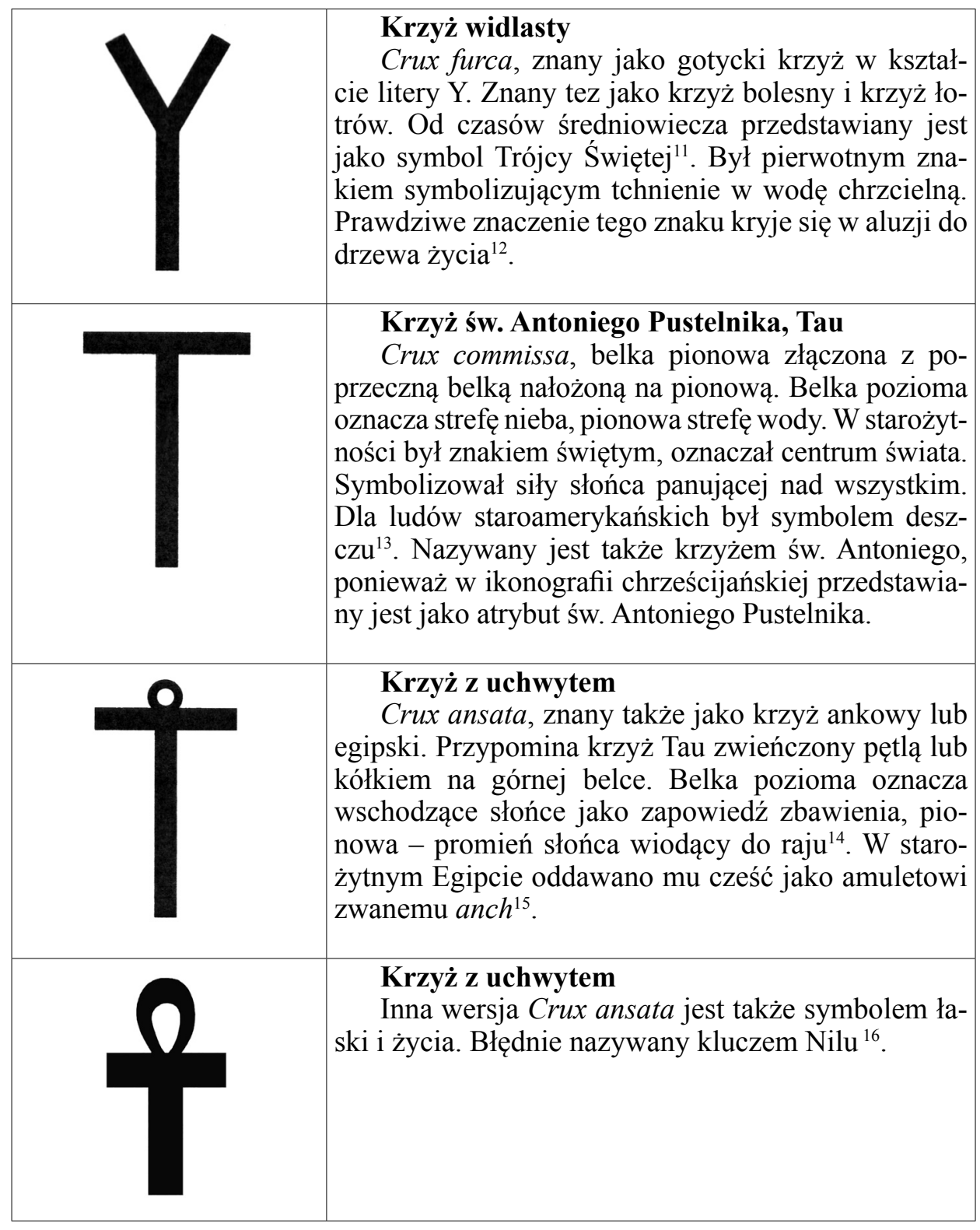

${ }^{11}$ Gigilewicz, Formy krzyża, s. 66.

${ }^{12}$ U. Janicka-Krzywda, Patron-atrybut-symbol, Poznań 1993, s. 214.

${ }^{13}$ Forstner, Świat symboliki chrześcijańskiej, s. 15.

${ }^{14} \mathrm{Na}$ grobach Koptów często ryto ten znak, będący symbolem krzyża. Forstner, Świat symboliki chrześcijańskiej, s. 14.

${ }^{15}$ Korabiewicz, Śladami amuletu, s. 37.

${ }^{16}$ Forstner, Świat symboliki chrześcijańskiej, s. 547. 


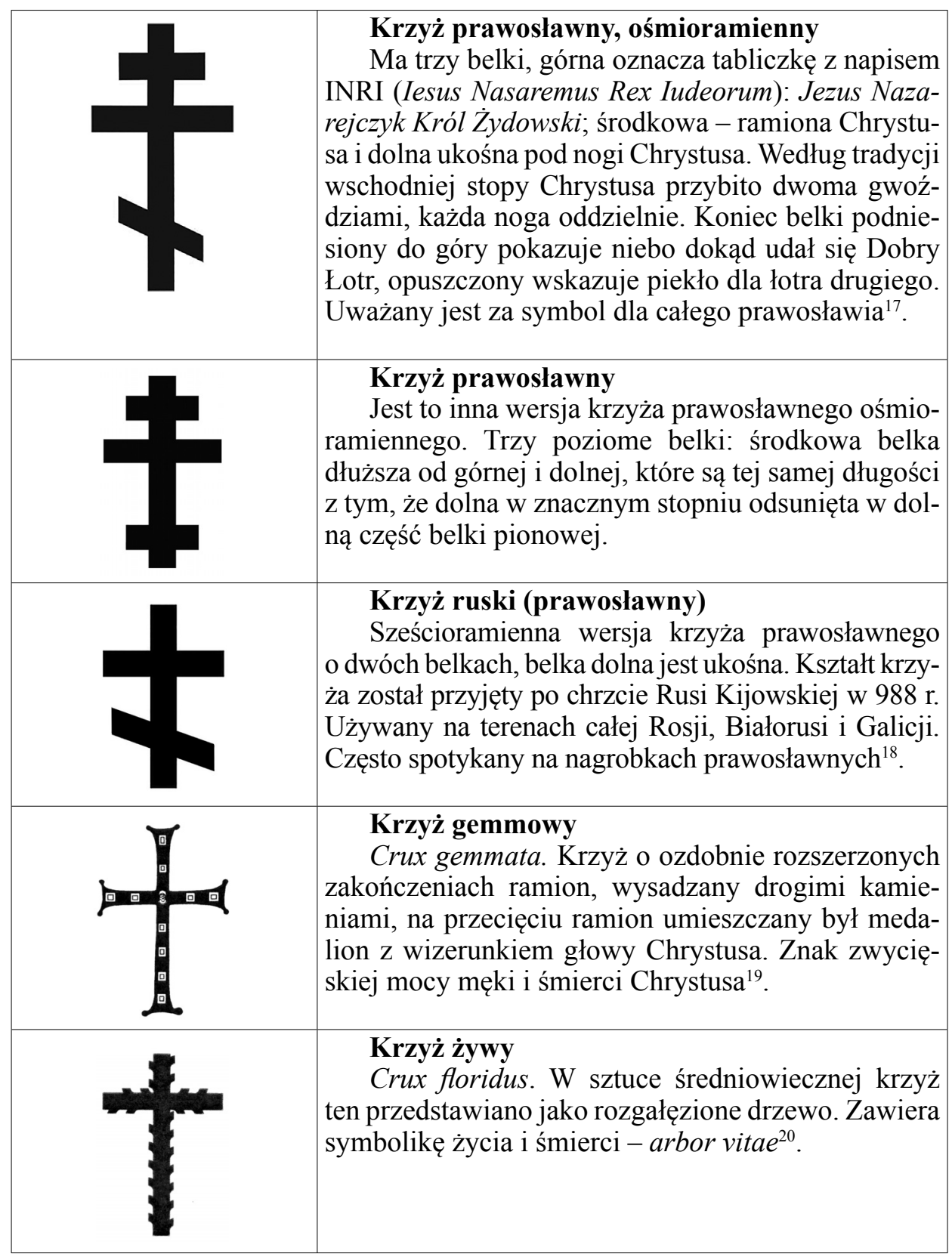

\footnotetext{
${ }^{17}$ Tamże, s. 15.

${ }^{18}$ M. Ramanûk, Belaruskiâ narodnyâ kryžy: managrafiâ, Vil'nâ 2000, s. 118.

${ }^{19}$ Filarska, Początki sztuki chrześcijańskiej, s. 322.

${ }^{20}$ Gigilewicz, Formy krzyża, s. 67.
} 


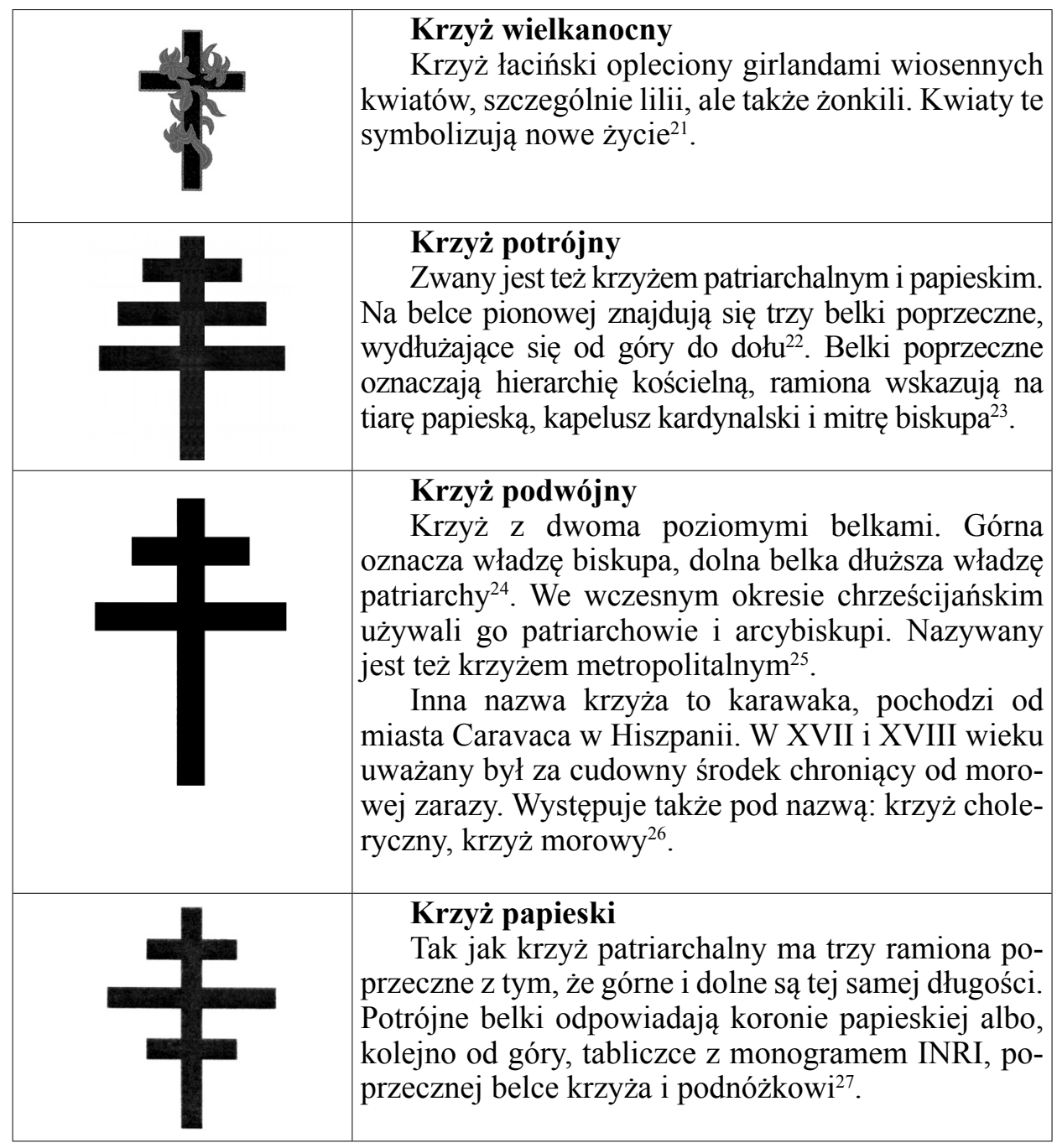

21 Tamże, s. 68.

22 Tamże, s. 70 .

23 Janicka-Krzywda, Patron-atrybut-symbol, s. 214.

${ }^{24}$ Tamże.

${ }^{25}$ Forstner, Świat symboliki chrześcijańskiej, s. 545.

${ }^{26}$ Bardzo popularny w Polsce pod koniec XVIII, w XIX i na początku XX wieku. Wieczorek http://krajoznawca.org/kg16/277-krzyz-historia-symbolika (dostęp: 23.03.2018).

27 Taylor, Przewodnik po symbolice Kościoła, s. 68. 


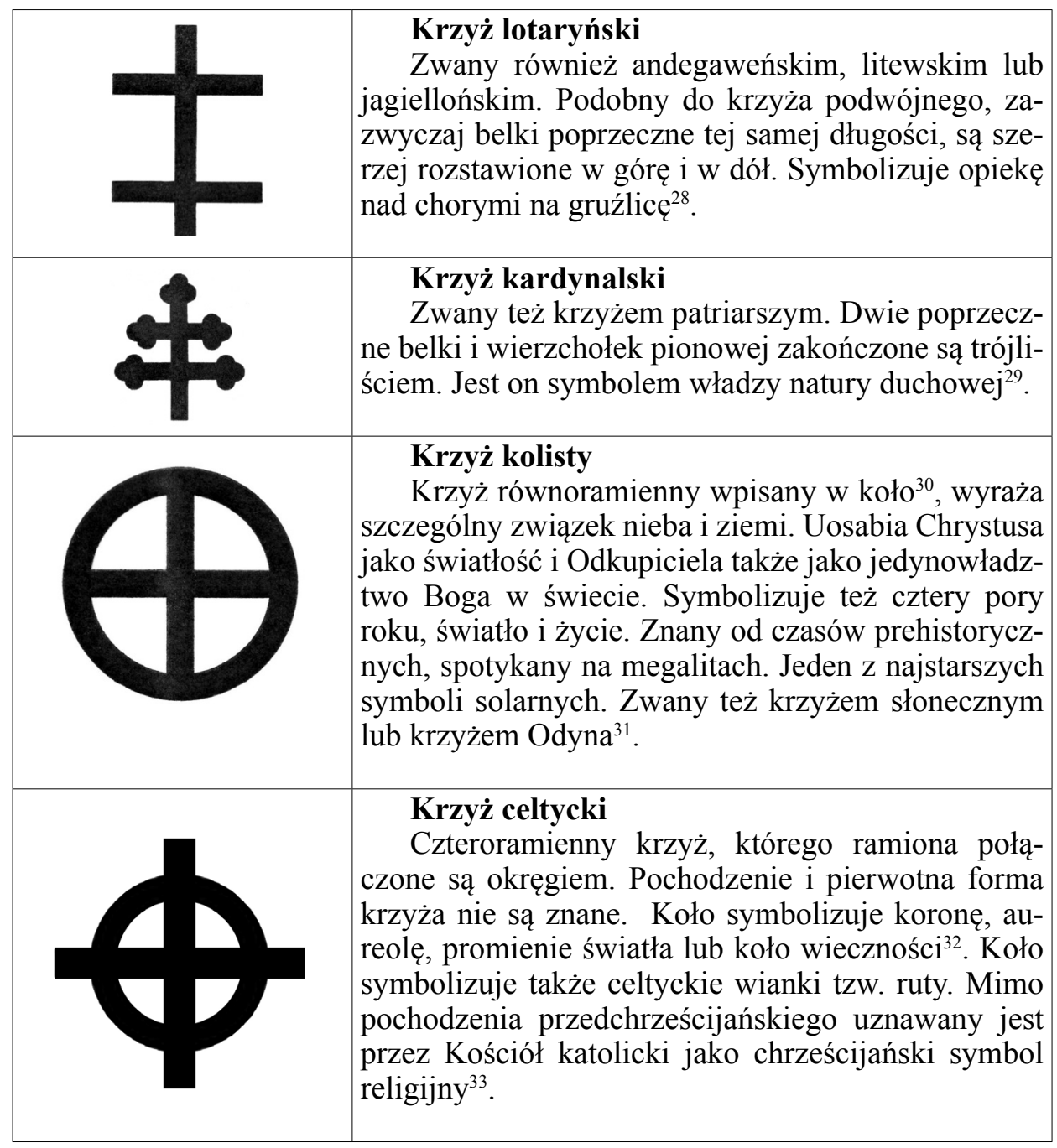

${ }^{28}$ M. Szczepaniak, Krzyż w życiu i przestrzeni publicznej, http://miroslaw.szczepaniak.neon24. pl/post/99352,krzyz-w-zyciu-i-przestrzeni-publicznej (dostęp: 23.03.2018).

${ }^{29}$ Wieczorek, http://krajoznawca.org/kg16/277-krzyz-historia-symbolika (dostęp: 23.03.2018).

${ }^{30}$ Krzyż wpisany w koło popularny był zwłaszcza w epoce brązu; na obszarze Europy środkowej, używany był w charakterze talizmanu; niewykluczone, że kryje się pod tym znaczenie solarne. Lurker, Przestanie symboli w mitach, kulturach i religiach, s. 386.

${ }^{31}$ E. Wieczorek, http://krajoznawca.org/kg16/277-krzyz-historia-symbolika (dostęp: 23.03.2018).

${ }^{32}$ Taylor, Przewodnik po symbolice Kościoła, s. 68.

${ }^{33}$ W. Ziehr, Das Kreuz: Symbol, Gestalt, Bedeutung, Stuttgart 1997, s. 110-111. 


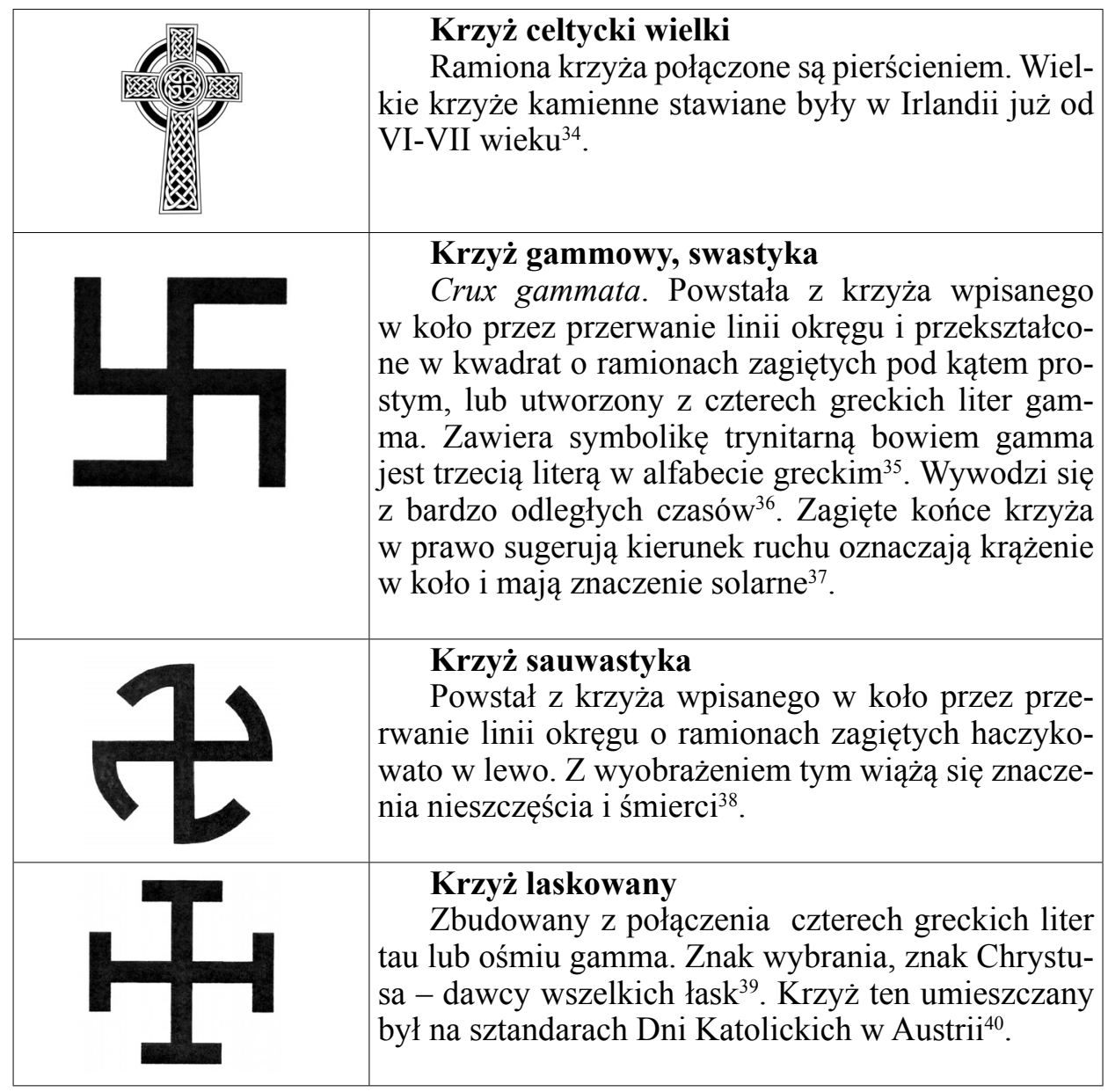

${ }^{34}$ Lurker, Przestanie symboli w mitach, kulturach i religiach, s. 387.

${ }^{35}$ Gigilewicz, Formy krzyża, s. 66.

${ }^{36}$ U buddystów oznacza klucz do raju, w sanskrycie jest znakiem świętym, znajduje się także u Germanów i Skandynawów. W ornamentyce kościelnej stylu romańskiego swastykę traktowano jako znak chroniący przed szatanem. Forstner, s. 14.

${ }^{37} \mathrm{~W}$ Indiach swastyka jest symbolem wiecznej cyrkulacji i zarazem Buddy, który przezwyciężył cykl narodzin. Lurker, Przestanie symboli w mitach, kulturach i religiach, s. 385.

${ }^{38}$ Tamże.

${ }^{39} \mathrm{http}: / /$ www.genealogia.okiem.pl/glossary/herby_graf.php?slowa_kluczowe=/krzyz/ (dostęp: 23.03.2018).

${ }^{40}$ Forstner, Świat symboliki chrześcijańskiej, s. 15. 


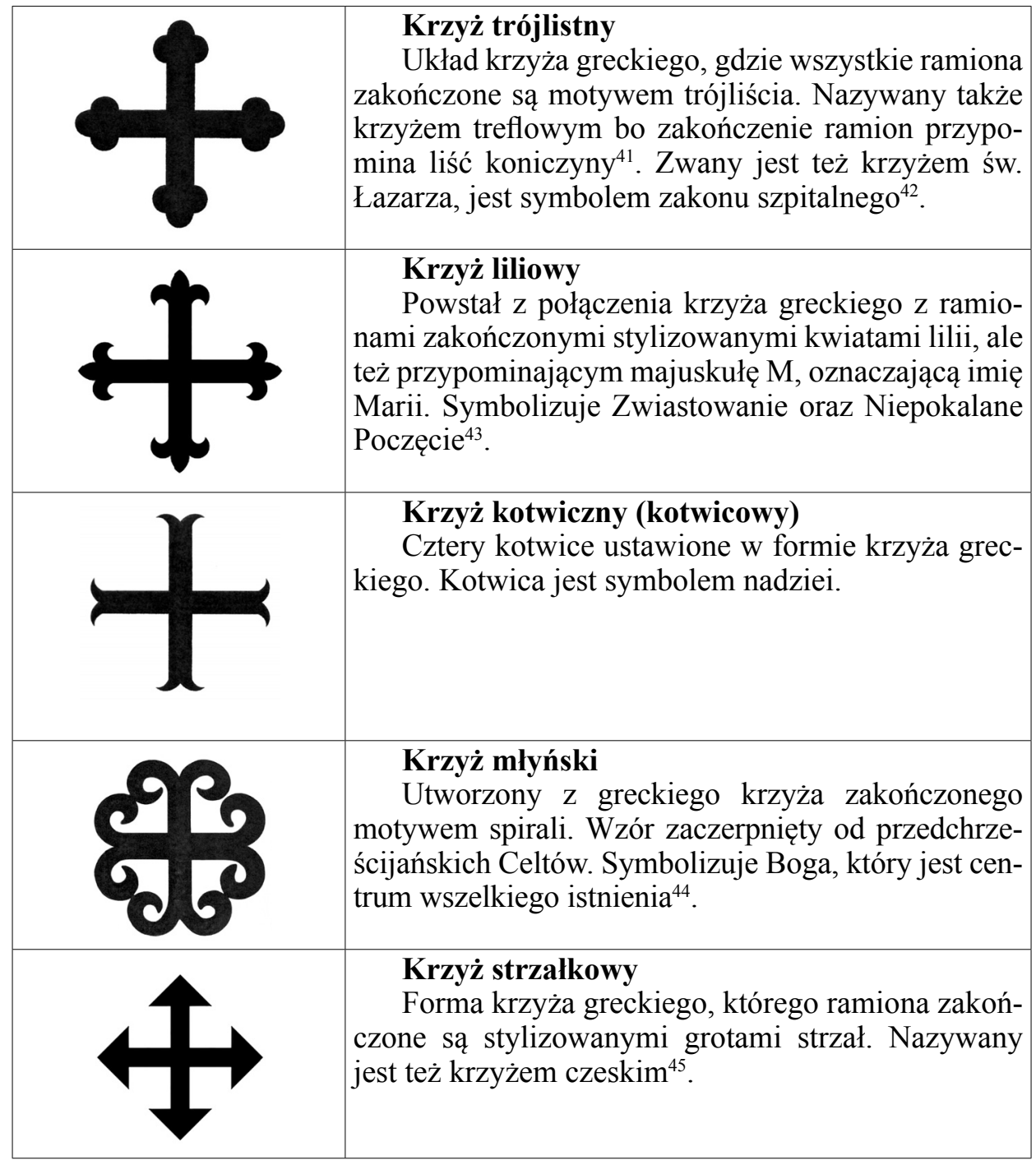

${ }^{41}$ Tamże, s. 547.

${ }^{42}$ Wieczorek, Krzyż - historia i symbolika, http://krajoznawca.org/kg16/277-krzyz-historia-symbolika (dostęp: 23.03.2018)

${ }^{43} \mathrm{~J}$. Kuśtowska, http://www.orator.salezjanie.kielce.pl/archiwum/14-10-temat.html (dostęp: 23.03.2018).

${ }^{44}$ Wieczorek, http://krajoznawca.org/kg16/277-krzyz-historia-symbolika (dostęp: 23.03.2018).

${ }^{45}$ Tamże. 


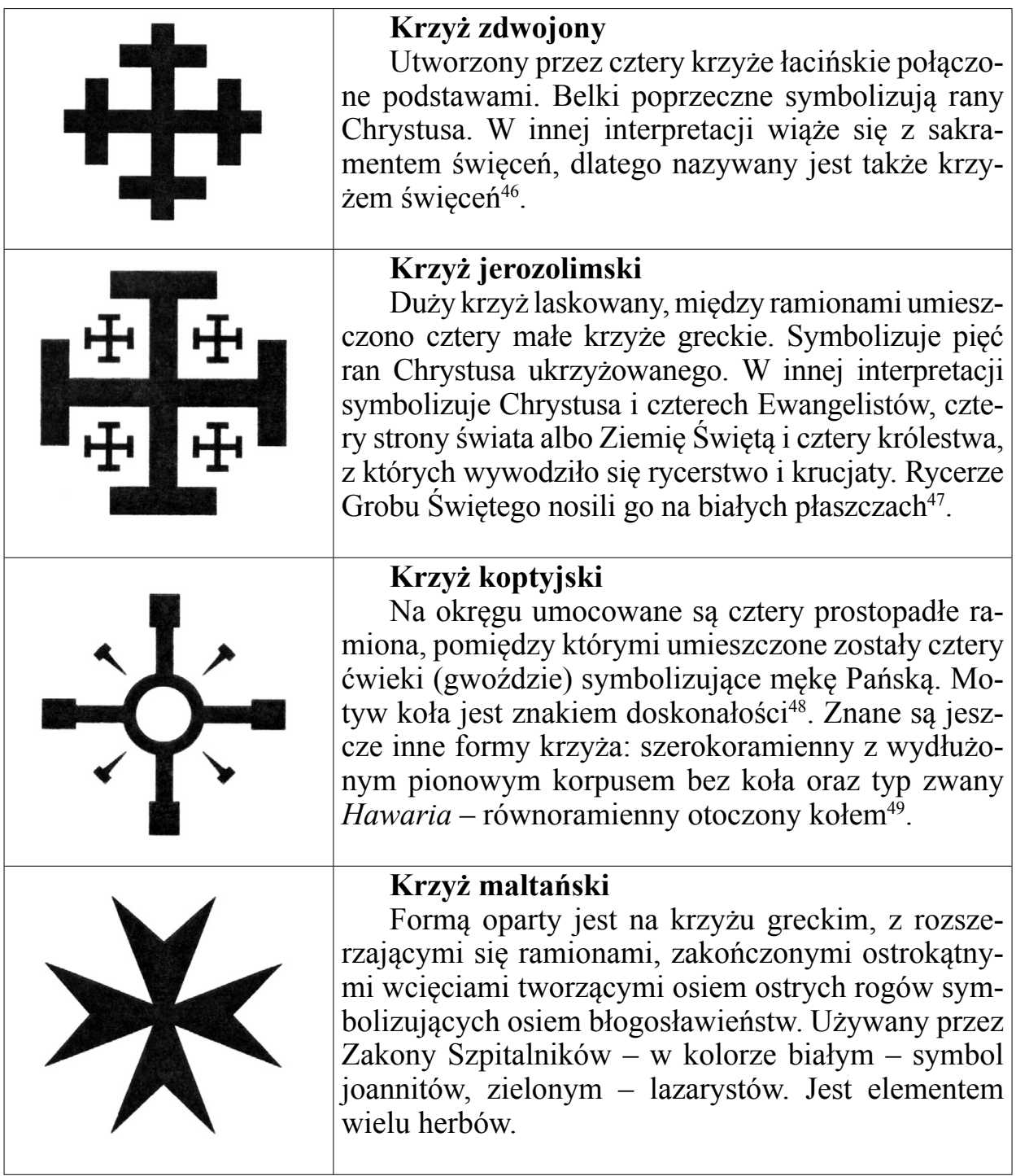

\footnotetext{
${ }^{46}$ Gigilewicz, Formy krzyża, s. 67.

${ }^{47}$ P. Dudziński, Alfabet heraldyczny, Warszawa 1997 s. 103.

${ }^{48}$ Gigilewicz, Formy krzyża, s. 67.

${ }^{49}$ W. Korabiewicz, Krzyż Koptyjski i jego naśladownictwa, Warszawa 1976, s. 10.
} 


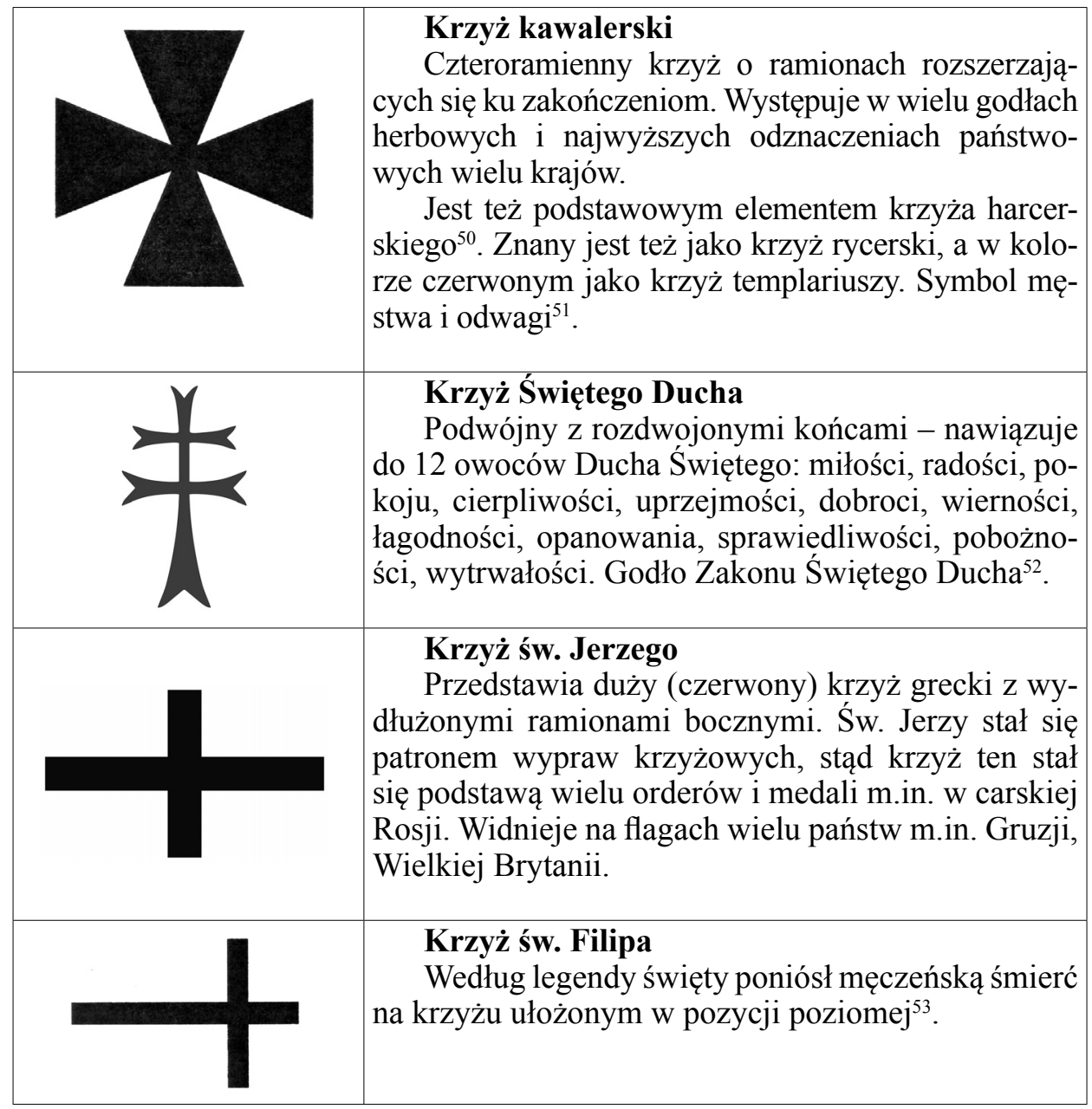

${ }^{50}$ Tamże.

${ }^{51}$ Za pontyfikatu papieża Eugeniusza III (1145-1153) templariusze otrzymali prawo do noszenia charakterystycznego czerwonego krzyża na płaszczach. M. Barber, Templariusze, Warszawa 1999, s. 67.

${ }^{52}$ Wieczorek, http://krajoznawca.org/kg16/277-krzyz-historia-symbolika (dostęp: 23.03.2018).

${ }^{53} \mathrm{http}: / /$ slideplayer.pl/slide/1216012/ (dostęp: 28.03.2018). 


Krzyż św. Jakuba
Krzyż ma kształt miecza lub sztyletu. Podstawą
krzyża jest ostrze, a ramiona i zwienczenie są w formie
kwiatów lilii.
Znanych jest co najmniej osiem odmian tego krzy-
ża, różniących się przeważnie kształtem poprzecznej
belki i zwieńczenia. Najczęściej przedstawiany jest
w kolorze czerwonym na białym tle. Jest symbolem Za-
konu św. Jakuba z Composteli oraz świętych wojowni-
ków, krzyżowców, rycerzy i walczących za wiarę5.

${ }^{54}$ Wieczorek, http://krajoznawca.org/kg16/277-krzyz-historia-symbolika (dostęp: 23.03.2018).

${ }^{55} \mathrm{http}: / /$ www.stpatricksday.com/spdc_content/history/saint-patricks-cross/(dostęp: 28.03.2018).

${ }^{56} \mathrm{Na}$ rewersie widnieje krzyż - na belce pionowej znajdują się litery: $C S S M L$ oznaczające: Crux Sacra Sit Mihi Lux, zaś na belce poprzecznej litery: NDSMD oznaczające: Non Draco Sit Mihi Dux. Krzyż otoczony literami: po prawej znajdują się litery VRSNSMV (Vade Retro Satana, Numquam Suade Mihi Vana) od lewej - SMQLIVB (Sunt Mala Quae Libas, Ipse Venena Bibas). Awers zawiera postać świętego ubranego w strój zakonny. Medalik Krzyż św. Benedykta, oprac. J. Gwiazda, Warszawa 2017, s. 17-18

${ }^{57}$ Gigilewicz, Formy krzyża, s. 71. 


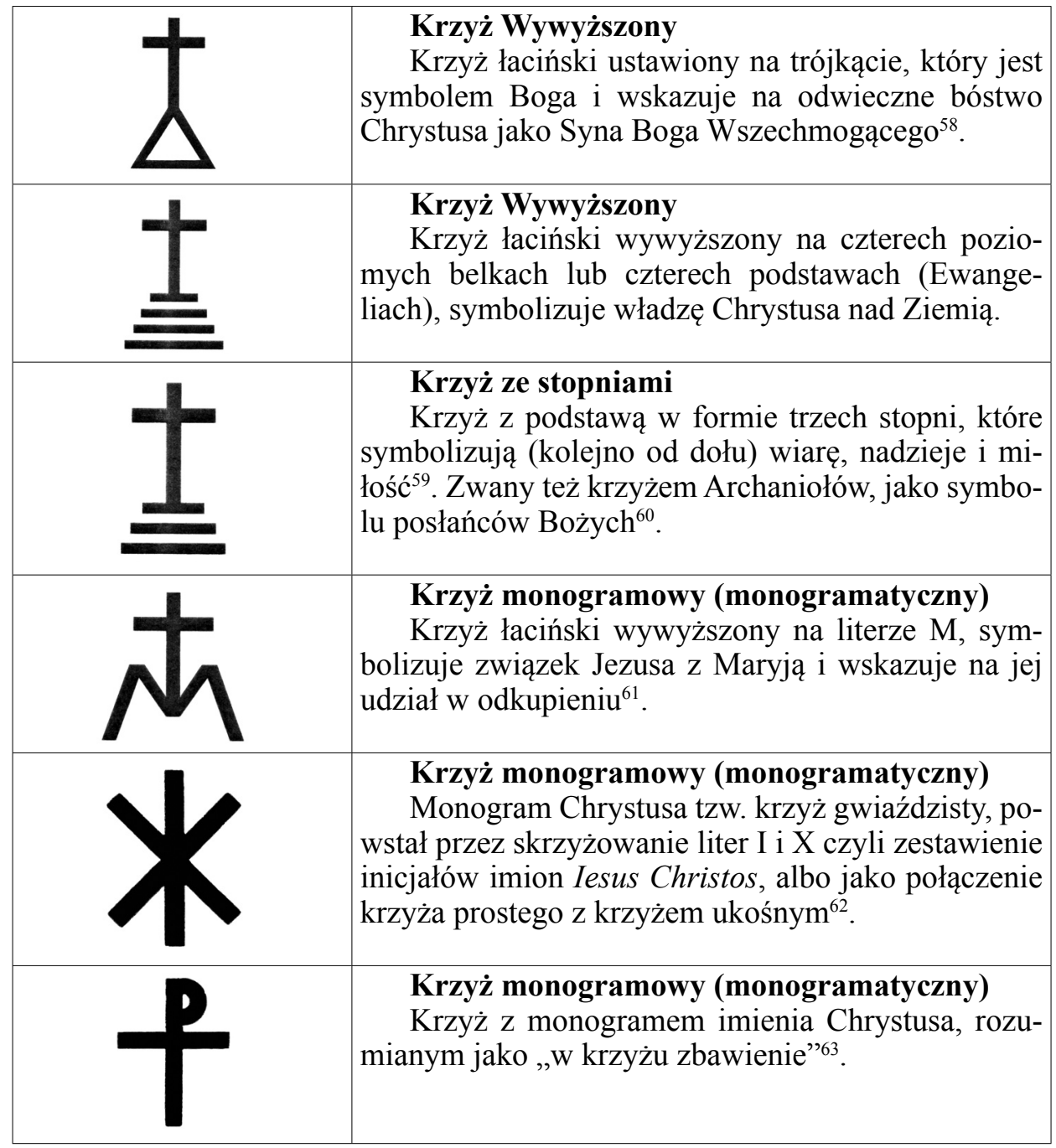

\footnotetext{
${ }^{58}$ Tamże, s. 70.

${ }^{59}$ Taylor, s. 68.

${ }^{60} \mathrm{http}: / /$ slideplayer.pl/slide/1216012/ (dostęp: 28.03.2018).

${ }^{61}$ Gigilewicz, Formy krzyża, s. 70.

${ }^{62}$ Tamże, s. 71.

${ }^{63}$ Tamże.
} 


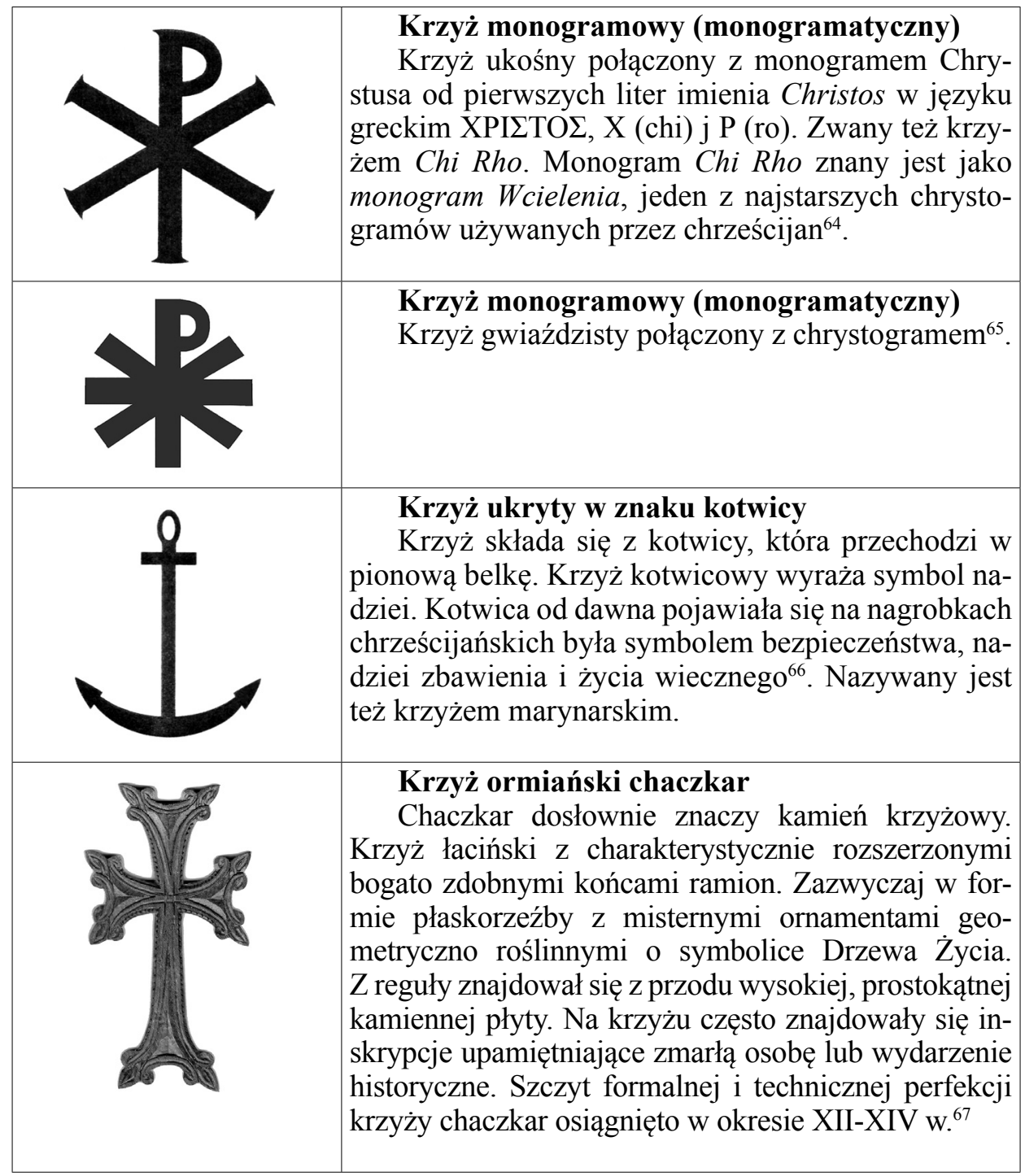

${ }^{64}$ Ziehr, Das Kreuz: Symbol, s. 235.

${ }^{65}$ Forstner, Świat symboliki chrześcijańskiej, s. 547.

${ }^{66}$ Taylor, Przewodnik po symbolice Kościoła, s. 63-64.

${ }^{67}$ V. Nersessian, Treasures from the Ark: 1700 years of armenian christan art, London 2001, s. 110 . 


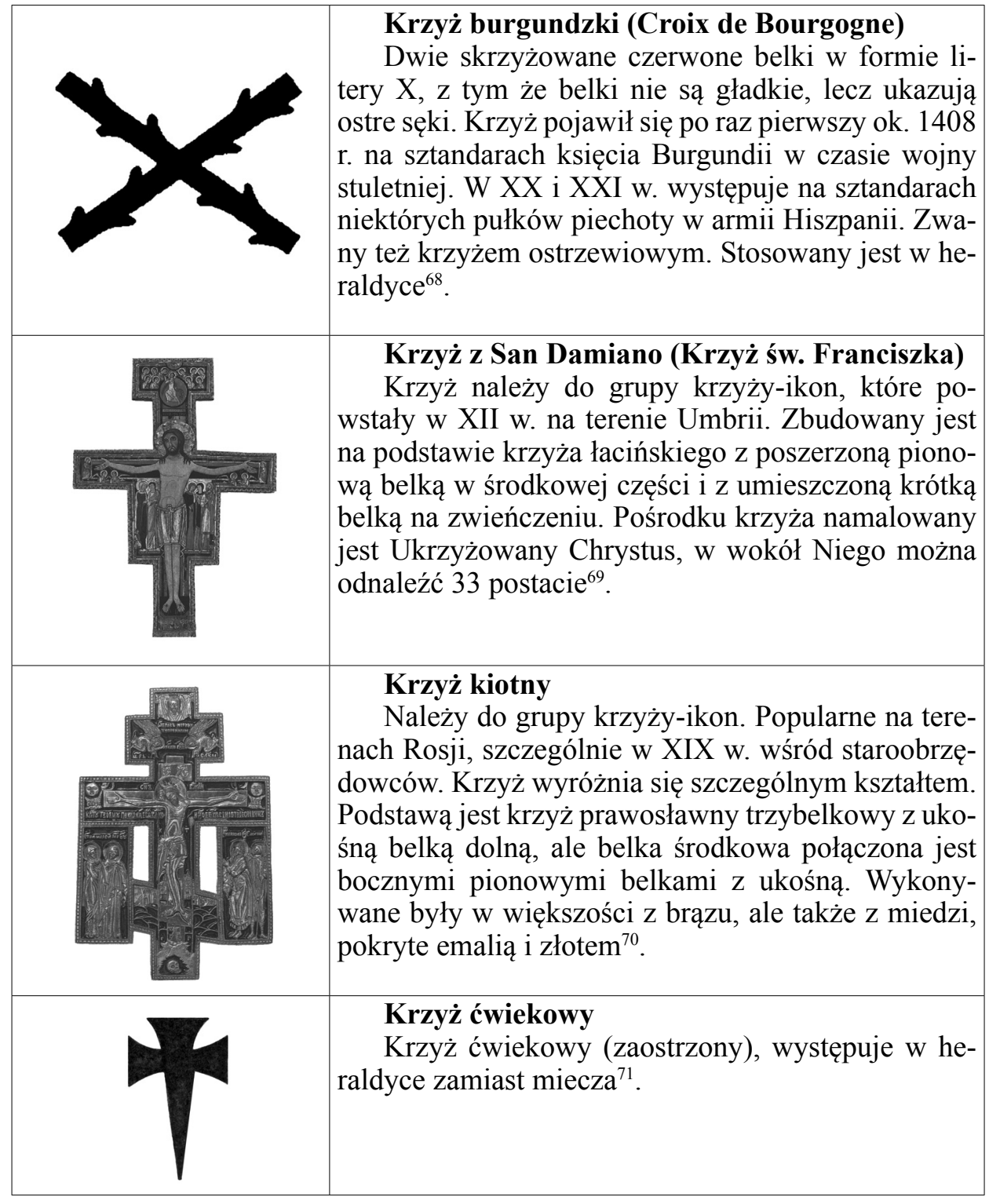

${ }^{68}$ Wieczorek, http://krajoznawca.org/kg16/277-krzyz-historia-symbolika (dostęp: 23.03.2018).

${ }^{69}$ Krzyż przedstawia abstrakcyjną grę kolorów (dominują trzy kolory: czerwony, złoty i czarny. Pierwszy symbolizuje miłość ofiarną, drugi - godność królewską i światło Boże, zaś trzeci - noc, grzech, śmierć i królestwo umarłych), nieskomplikowaną kompozycją i ciekawą formę. T. Jank, Ikona Krzyża z San Damiano, Niepokalanów 2007, s. 9, 23-25.

${ }^{70}$ Znane były już w czasach starożytnych, miały różne zastosowania w różnych miejscach, np. były znakami świętych miejsc lub dróg. Czym jest krzyż kiotny http://nextews.com/94380ad5/ (dostęp: 28.03.2018).

${ }^{71}$ Wieczorek, http://krajoznawca.org/kg16/277-krzyz-historia-symbolika (dostęp: 23.03.2018). 


Czerwony Krzyż
Wszystkie ramiona równe tak jak w krzyżu grec-
kim, lecz bardziej masywne. Czerwony, na białym
tle, został neutralnym znakiem Organizacji Między-
narodowego Czerwonego Krzyża. Głównym celem
działania jest pomoc poszkodowanym w wyniku kon-
fliktów zbrojnych ${ }^{72}$.

${ }^{72}$ MCK powstał w 1863 r., założony przez Henryego Dunanta. Jest to organizacja humanitarna z siedzibą w Genewie. Międzynarodowy Komitet Czerwonego Krzyża, MKCK, zrzesza wiele organizacji z różnych krajów. Czerwony Krzyż. Wiadomości. http://prawo.sejm.gov.pl/isap.nsf/DocDetails.xsp?id=WDU19230620458 ogólne, oprac. W. Wierzbicki, Katowice 1995 (dostęp: 30.03.2018).

${ }^{73} \mathrm{http}: / /$ epral.fr/croix_huguenote.php (dostęp: 28.03.2018).

${ }^{74} \mathrm{~W}$ ciągu dwóch stuleci wygląd krzyża ulegał zmianom. Order Virtuti Militari, red. K. Filipow, G. Jasiński, Warszawa 2013.

${ }^{75}$ Ustanowiony dla uczczenia zwycięstwa w bitwie pod Zieleńcami w czasie wojny polsko-rosyjskiej 1792 r. podczas interwencji Imperium Rosyjskiego i Konfederacji Targowickiej przeciwko Konstytucji 3 maja. Dewiza orderu brzmi: Honor i Ojczyzna. Wprowadzone było pięć klas krzyża: Wielki, Komandorski, Kawalerski, Złoty i Srebrny. Order Virtuti Militari, s. 15-16. 


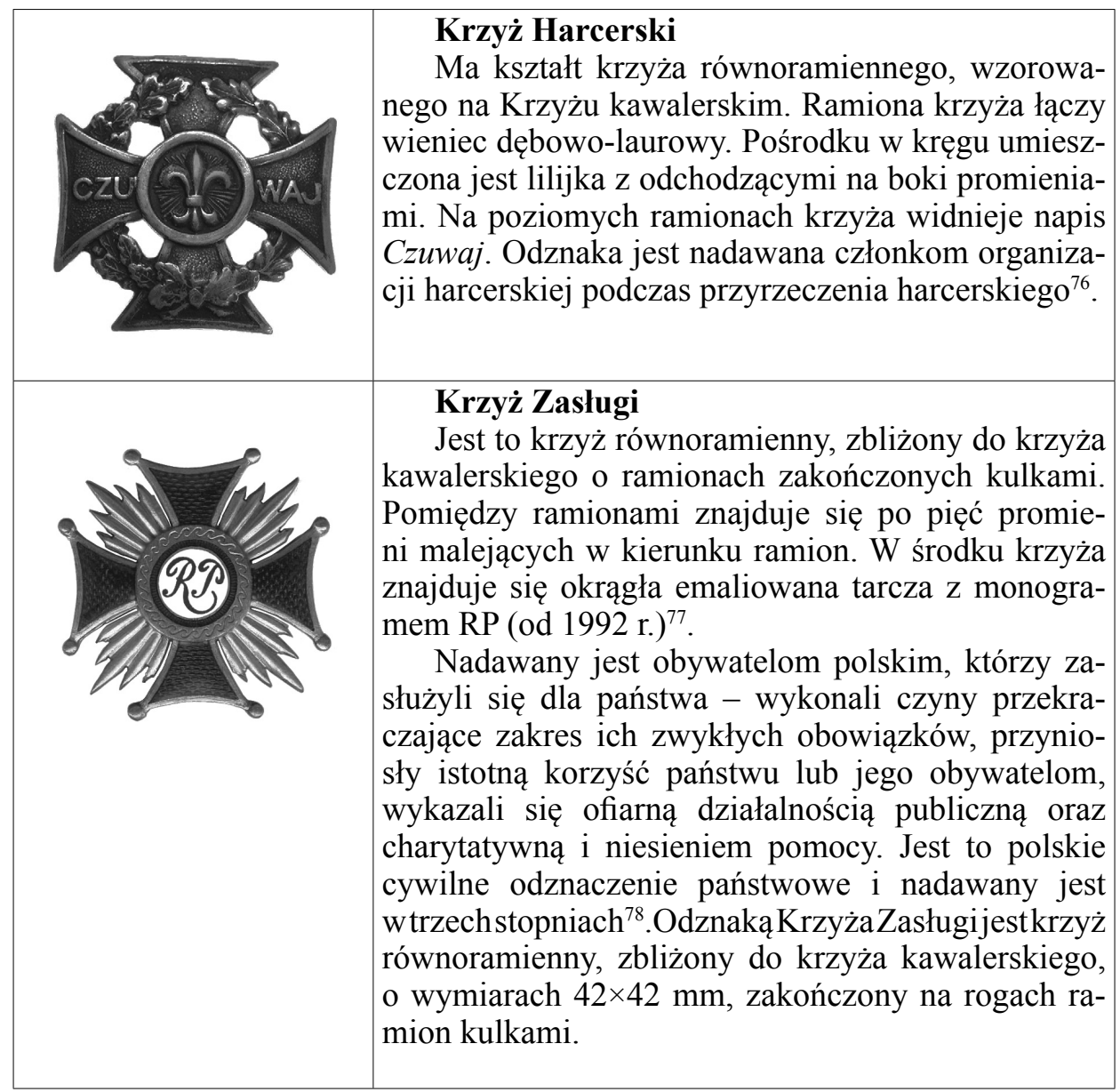

Źródło ilustracji krzyży ${ }^{79}$.

${ }^{76}$ Kształt krzyża został ustalony 1-2 listopada 1918 r., w czasie konferencji zjednoczeniowej Związku Harcerstwa Polskiego. T. Sikorski, Krzyż harcerski 1913-1989, Kraków 1991.

${ }^{77}$ Nadawane są trzy stopnie krzyża: Złoty, Srebrny i Brązowy Krzyż Zasługi. http://www.prezydent. pl/prezydent/kompetencje/ordery-i-odznaczenia/odznaczenia/krzyz-zaslugi/ (dostęp: 23.03.2018).

${ }^{78}$ Ustanowiony na mocy ustawy w 1923 r.. Ustawa z dnia 23 czerwca 1923 r. o ustanowieniu „Krzyża Zastugi” (Dz.U. z 1923 r. Nr 62, poz. 458) http://prawo.sejm.gov.pl/isap.nsf/DocDetails. xsp?id=WDU19230620458 (dostęp: 23.03.2018).

${ }^{79}$ Rysunki krzyży - wykorzystano z opracowań: E. Gigilewicz, Formy krzyża, w: Krzyż, red. E. Kasjaniuk, Lublin 2011 ; E. Wieczorek, http://krajoznawca.org/kg16/277-krzyz-historia-symbolika; R. Taylor, Przewodnik po symbolice kościoła, Warszawa 2006; W. Ziehr, Das Kreuz : Symbol, Gestalt, Bedeutung, Stuttgart 1997; D. Forstner Świat symboliki chrześcijańskiej, Warszawa 200 ; https://pl.wikipedia.org/wiki/Krzy\%C5\%BC; Czym jest krzyż kiotny http://nextews.com/94380ad5/; http://www.prezydent.pl/prezydent/kompetencje/ordery-i-odznaczenia/odznaczenia/krzyz-zaslugi/; http://prawo.sejm.gov.pl/isap.nsf/DocDetails.xsp?id=WDU19230620458 (dostęp: 30.03.2018). 
W ciągu wieków pojawiało się wiele rodzajów krzyży. Posiadały one różne formy, znaczenie i symbolikę. W czasach prehistorycznych krzyż był amuletem, chronił przed złymi mocami, ale też symbolizował bóstwa. Krzyże były związane zazwyczaj z formą kultu sił przyrody, a w szczególności ognia, słońca oraz życia. Krzyże były noszone i tatuowane, rysowane i malowane na skałach, wyrabiano je $\mathrm{z}$ różnych materiałów, stawiano krzyże kamienne i drewniane, a także metalowe.

Zanim krzyż stal się symbolem dla chrześcijan, był utożsamiany z narzędziem tortur, najgorszym z narzędzi męki, szubienicą. Ukrzyżowanie było najbardziej okrutną i haniebną karą śmierci stosowaną przez Rzymian. Karę śmierci stosowano tylko wobec niewolników, przestępców i innych (obcych) ludów, nigdy wobec obywateli rzymskich. Wraz z męczeńską śmiercią Chrystusa krzyż stał się jednym z najważniejszych symboli chrześcijaństwa. Krzyż jako znak zbawienia jest także atrybutem wielu świętych, których życie w szczególny sposób było z nim powiązane.

Oprócz form krzyża związanego z religiami powstało wiele jego odmian pozareligijnych. Powszechny jest zwyczaj nadawanych obywatelom „krzyży” za wybitne zasługi będące wyrazem patriotyzmu, osiągnięć naukowych i społecznych.

Jako prosty i mocny znak graficzny, krzyż występuje w różnych kulturach i strefach językowych. W wiekach minionych znajdujemy go w sztuce heraldycznej i państwowotwórczej. W czasach popkultury krzyż pojawił się także w kompozycjach infografiki, a nawet znaków firmowych.

\section{BIBLIOGRAFIA}

\section{Źródła}

http://www.prezydent.pl/prezydent/kompetencje/ordery-i-odznaczenia/odznaczenia/krzyz-zaslugi/ (dostęp: 30.03.2018).

Ustawa z dnia 23 czerwca 1923 r. o ustanowieniu „Krzyża Zasługi”, (Dz.U. z 1923 r. Nr 62, poz. 458) ) http://prawo.sejm.gov.pl/isap.nsf/DocDetails.xsp?id=WDU19230620458 (dostęp: 23.03.2018).

\section{Opracowania}

Barber Malcolm, Templariusze, Warszawa 1999.

Czerwony Krzyż. Wiadomości ogólne, oprac. W. Wierzbicki, Katowice 1995.

Dudziński Paweł, Alfabet heraldyczny, Warszawa 1997.

Forstner Dorothea, Swiat symboliki chrześcijańskiej, Warszawa 2001.

Gigilewicz Edward, Formy krzyża, w: Krzyż, red. E. Kasjaniuk, Lublin 2011.

Janicka-Krzywda Urszula, Patron atrybut symbol, Poznań 1993.

Jank Tomasz, Ikona krzyża z San Damiano, Niepokalanów 2007.

Korabiewicz Wacław, Krzyż Koptyjski i jego naśladownictwa, Warszawa 1976. 
Lurker Manfred, Przesłanie symboli w mitach, kulturach i religiach, Kraków 1994.

Medalik Krzyż św. Benedykta, oprac. J. Gwiazda, Warszawa 2017.

Nersessian Vrej, Treasures from the Ark: 1700 years of armenian christan art, London 2001.

Order Virtuti Militari, red. K. Filipow, G. Jasiński, Warszawa 2013.

Ramanûk Mihas', Belaruskiâ narodnyâ kryžy: managrafiâ, Vìl'nâ 2000.

Sepioł Alfred, Krzyż - znak wiary i kultury, Jasło 2013.

Skubiszewski Piotr, La croix dans le premier art chrétien, Paris 2002.

Taylor Richard, Przewodnik po symbolice Kościoła, Warszawa 2006.

Uspieński Boris, Krzyż i koło, Gdański 2010.

Ziehr Wilhelm, Das Kreuz: Symbol, Gestalt, Bedeutung, Stuttgart 1997.

\section{Netografia}

Czym jest krzyż kiotny http://nextews.com/94380ad5/ (dostęp:

Kuśtowska Justyna, http://www.orator.salezjanie.kielce.pl/archiwum/14-10-temat.html (dostęp: 23.03.2018).

Szczepaniak Mirosław, Krzyż w życiu i przestrzeni publicznej, http://miroslaw.szczepaniak. neon24.pl/post/99352,krzyz-w-zyciu-i-przestrzeni-publicznej (dostęp: 23.03.2018).

Wieczorek http://krajoznawca.org/kg16/277-krzyz-historia-symbolika (dostęp: 23.03.2018).

\section{KRZYŻ JAKIEGO NIE ZNAMY}

\section{Streszczenie}

W ciągu wieków pojawiało się wiele rodzajów krzyży. Posiadały one różne formy, znaczenie i symbolikę. W czasach prehistorycznych krzyż był amuletem, chronił przed złymi mocami, ale też symbolizował bóstwa. Krzyże były związane zazwyczaj z formą kultu sił przyrody, a w szczególności ognia, słońca oraz życia. Krzyże były noszone i tatuowane, rysowane i malowane na skałach, wyrabiano je z różnych materiałów, stawiano krzyże kamienne i drewniane, a także metalowe. Zanim krzyż stal się symbolem dla chrześcijan, był utożsamiany z narzędziem tortur, najgorszym z narzędzi męki. Wraz ze śmiercią Chrystusa, krzyż stał się jednym z najważniejszych symboli chrześcijaństwa. Krzyż jako znak zbawienia jest także atrybutem wielu świętych, których życie w szczególny sposób było z nim powiązane.

Oprócz form krzyża związanego z religiami powstało wiele jego odmian pozareligijnych. Powszechny jest zwyczaj nadawanych obywatelom „krzyży” za wybitne zasługi będące wyrazem patriotyzmu, osiągnięć naukowych i społecznych. W czasach popkultury krzyż pojawił się także w kompozycjach infografiki, a nawet znaków firmowych.

Słowa kluczowe: krzyż; krucyfiks; wizerunki krzyża 


\title{
A CROSS WE DO NOT KNOW
}

\begin{abstract}
Summary
Throughout centuries a number of crosses appeared. They had different forms, meanings and symbolism. In prehistoric times, a cross was an amulet, it protected against evil powers, but it also symbolized deities. Crosses were usually connected with the cult of nature forces, particularly fire, the sun and life. Crosses were worn, tattooed, drawn and painted on rocks; they were made of various materials: stone wood and metal. Before a cross became a symbol of Christianity, it had been identified with an instrument of torture, as the worst of all. After the death of Christ, a cross became one of the most important symbols of Christianity. A cross as a sign of salvation is also an attribute of numerous saints, whose lives were connected in a special way with it.

In addition to the forms of a cross associated with religions, a number of non-religious variations exist. It is the common custom to award people 'crosses' for outstanding services stemming from patriotism, scientific and social achievements. In a time of pop culture, a cross also appeared in the compositions of infographics, and even company logos.
\end{abstract}

Keywords: a cross; a crucifix; images of a cross 